\title{
Changing the Paradigm of Education for Security
}

\author{
Andrzej Pieczywok*
}

\section{Introduction}

In our lives we are often exposed to situations that increase the likelihood that existing conditions in our surroundings will deteriorate, risking a loss of balance between our system of values and our capacities. These situations can have a significant influence on people's sense of existential security. Among the many processes that reflect this modern reality, one seems to be particularly dominant: globalization. Its inevitability and extent can be observed not only in the sphere of production and trade, but on the level of our daily experiences. ${ }^{1}$

It seems that the modern world regularly presents threats to our security other than the dangerous physical, chemical, and biological factors that result in occupational diseases or accidents. Occupational diseases, which have long caused various forms of physical disability, are now associated increasingly often with emotional instability, fear, and depression. We live in a world of permanent and rapid change, a world that offers freedom and closer contact with other people - mainly thanks to the development of global communication networks and the extraordinarily rapid development of mass media. At the same time, however, we live in a world that often works against our sense of security. $^{2}$

The status of education as the great hope of the present is itself at risk, as it is subject to many contradictions, tensions, and failures. Today, we see the lowering of the prestige of many of the humanistic, social, and cultural disciplines as a result of views based in mechanical or psychological reductionism. Education is a social process, organized in order to induce changes in humans. On one hand, education must prepare people to make use of the achievements of civilization, and on the other hand it should lead them toward creative participation in furthering civilization. It is particularly important in the pursuit of scientific truth, and in shaping pro-social and pro-peace attitudes. The modern

\footnotetext{
Lt. Col. Andrzej Pieczywok, Assoc. Prof., holds the doctorate in the field of the Humanities and the doctor habilitatus degree in the field of the Social Sciences. He is the faculty member of the National Security Faculty of the National Defence University, Warsaw. His research focuses on questions connected with shaping the commanding skills of the officers: commanders and lecturers, questions relating also to education for security, educational systems in the European Union and NATO.

1 The globalization process has been described particularly effectively by John Naisbitt and Francis Fukuyama. See John Naisbitt, Megatrends (Poznań: Zyski i S-ka, 1997), 80-105; Francis Fukuyama, "Globalizacja bez końca," Gazeta Wyborcza 11 (2000): 23; Gordon Dryden and Jeannette Vos, Rewolucja w uczeniu, trans. B. Jóżwiak (Poznań: Zyski i S-ka, 2003), 49.

2 See J. A. Pielkowa, "Pedagogika społeczna wobec zagrożeń współczesności," in Człowiek u progu trzeciego tysiąclecia. Zagrożenia $i$ wyzwania, vol. I., ed. M. Plopa (Elblagg: Elbląska Uczelnia Humanistyczno-Ekonomiczna, 2005), 61.
} 
world requires that education shape human creativity, provide support mechanisms for creative thinking, and aid students in adopting creative perspectives on the world as one that can change and transform.

Under current global conditions, the interdependence of local and global spheres provides the basic pattern of development and creative direction for human activity. And on both the local and global level, education is focused on shaping and developing the level of knowledge in society. This article presents a range of topics and research regarding the implementation of security education at every level of the curriculum. The scope of analysis primarily focuses on the content offered in lower secondary schools and middle schools.

Jerzy Kunikowski writes, "The general goal of school is to educate modern man, who will be equipped with a particular set of ethical rigor, which commonly can be called a formed conscience and set of beliefs about self, his identity and readiness." $3 \mathrm{Al-}$ though security is not typically thought of as part of the curriculum in primary and secondary schools, this does not mean that schools at this level do not have an important role to play in security education. The school as a critical educational institution cannot remain outside the mainstream of thinking about improving security. The overall objective of school education is to educate and raise the awareness of young people who not only will be able to quickly and accurately prevent a variety of threats, but also to define them and actively participate in activities related to ensuring security in the social environment.

\section{Security as an Educational Category}

Since the end of the Cold War, the concept of security has developed by leaps and bounds. Having been profoundly transformed and extended to include transnational dimensions, the concept of security is now oriented towards both human and global security. Human security is distinguished from the traditional concept of security both by the fact that the threats come from both within and outside the state and by its purpose, which is the protection of individuals. Global security, which also includes human security, takes into account a set of interconnected nonmilitary risks - economic crises, underdevelopment, environmental decline - that cross state borders and above all are beyond the state's powers of regulation.

New concepts of security are associated with a more general decline of state sovereignty. On one hand, individual citizens have replaced the state as primary holders of the right to security, while, on the other hand, the task of producing security "sans frontieres" has been taken over by international institutions and organizations.

Security as the primary value of human existence is one of the main subjects of discussion within both academic disciplines and the broader society. It is the object of the concerns, aspirations, and desires of people around the word. In this environment, it is important to promote actions that preserve peace. These operations are conditioned by the characteristics of human nature, and, on the other hand, by axiology, or the study of

3 Jerzy Kunikowski, Przygotowanie obronne spoleczeństwa (Warsaw: Bellona, 2001), 140-41. 
values. Human nature is an object of study of both philosophy (anthropological) and psychology (which examines in detail man's personality, disposition, development, and opportunity). Systems of values, on the other hand, are the area of study of axiology, a basic component of philosophy. Ethics, above all, establishes cardinal values that are appropriate to the adult human personality. Such a personality is attributed to man, as an entity essentially free to realize its dignity, because he is concerned with great matters. Since ancient times such a philosophical man is in every aspect a model in ethics, and has served as an important ideal in a responsible and fair system of education. ${ }^{4}$

Security, according to its strict definition, means a state of lack of threat, calmness, or certainty. This term is used in different ways in many different disciplines, however, and it is difficult to define. In the most general sense, it is the state in which an individual, a social group, an organization, or a nation does not sense a threat to its existence or basic interests. A secure situation is one in which there are formal, institutional, and practical guarantees of protection. In this sense, security can be perceived in emotional, personal, public, financial, economic, social, and international terms. ${ }^{5}$

In the literature, occupational safety is most often associated with hygiene, understood generally as a set of conditions that have a positive impact on human health. ${ }^{6}$ Since this understanding of occupational safety is quite general, it may contain both physical and emotional components. The Occupational Training Teacher Reference Dictionary focuses on a rather technical definition: occupational health and safety is "a set of means and utilities: technical, sanitary and hygienic, socioeconomic and organizational, which, through elimination or limitation of harmful and dangerous physical, chemical and biological factors, exerting impact on employees in the process of work, ensure the conditions of work and the environment, which eliminate the possibility of occurrence of occupational diseases and accidents at work...."

Two distinct perspectives on safety can be distinguished:

1. A "narrow" perspective, that can be described as a lack of threat, focusing on analysis of the impact on the subject in terms of threats to significant internal values

2. A "wide" perspective, that treats safety as shaping conditions that enable the achievement of a high probability of survival, possession, and freedom of development; a significant aspect here is ensuring the creative activity of the subject, or the ability to open up and to cooperate with the environment. ${ }^{8}$

4 J. Świniarski, "Przywództwo jako osnowa edukacji dla bezpieczeństwa," Zeszyty Naukowe AON 1 (2001): 134.

5 See http://leksykony.interia.pl/haslo?hid=173930.

6 See M. Szymczak, ed., Stownik języka polskiego, vol. I. (Warsaw: PWN, 1978), 147, 740.

7 E. Goźlińska and F. Szlosek, Podręczny stownik nauczyciela ksztatcenia zawodowego (Radom: Institute for Technology of Operation, 1997), 10.

8 M. Cieślarczyk, "Społeczeństwa i społeczności na przełomie wieków - od bezpieczeństwa kultury do kultury bezpieczeństwa?" in Bezpieczeństwo w perspektywie socjologicznej (Warsaw: WBBS, 2001), 31-32. 
At the macro level, security is treated as the real condition of internal stability and sovereignty of the state, which reflects the absence of any threats (in the sense of the satisfaction of the basic existential and behavioral needs of society and the state's secure status as a sovereign subject in international relations). ${ }^{9}$ In the past, issues of security were limited to political and military aspects, but the modern notion of state security includes economic, environmental, social, and ethnic aspects. Still treated as valid are such threats to personal and structural security as violation of the economic, political, moral, and legal order in the society. But also considered as threats to security are such issues as a lack of understanding and compliance on the part of individuals and states with the rule of law or the pursuit of individual interests at any price without considering the common good. Many of these threats have not been eliminated, and they may still pose a potential threat of new conflicts and wars that could ruin the economy, culture, and security of human societies. ${ }^{10}$

In today's multipolar world, the parameters of the new security landscape are particularly complex. They include a large number of processes and actors, all with particular needs, interests, ideologies, and strategies. In this context, the nature of risk as social construct and the increasing number of situations perceived as risk place a multifaceted and unsolvable risk-security ambivalence at the very heart of the matter.

A key aspect is the fact that the expansion of the concept of security makes it difficult to fully achieve. The problem is further complicated by the fact that, in many situations, it is now, paradoxically, more difficult to distinguish between security measures and sources of risk. Furthermore, public opinion is well aware of the fact that all security measures are also sources of risk - there is no such thing as safe security.

All human activities can be a source of threats and risks. The economy represents an emblematic case. While it is frequently emphasized that the real problem with economic globalization does not affect those involved, but rather those excluded, the increase of investments in regions on the verge of conflict or actually at war and the consolidated policy of international aid during post-war peace-building initiatives has created of new opportunities, but also has generated new risks and instabilities. Consequently, many resources and shrewd care are required.

Paradoxically, even the widely approved defense of human security and human and minority rights and the condemnation of crimes against humanity - a cause of great ferment among organized forms of civil society, spontaneous groups, and even public opinion-can produce undesired effects. Indeed, increased social sensitivity can involuntarily stimulate new conflicts. All minorities can constitute sources of internal conflict in the name of equality, human and cultural rights, and self-determination (among others) in the hope of protecting their ethnic and religious distinctness and attracting the attention and support of the international community for their policies of autonomy, regardless of the grounds upon which they are based.

\footnotetext{
9 See Stanislaw Dworecki, "Zagrożenia bezpieczeństwa państwa," in Słownik terminów z zakresu bezpieczeństwa narodowego (Warsaw: AON, 2002), 16.

10 Ryszard Rosa, Filozofia bezpieczeństwa (Warsaw: Bellona, 1995), 232.
} 
The concept of risk involves accounting for the probability of an event, while the calculation of this probability requires an interconnected combination of expert knowledge, common sense, opinions, assessments, indicators, and other objective and subjective aspects. Furthermore, all risks have a social dimension. Thus security is a public asset that also has a significant symbolic value.

Increasing citizens' sense of security refers to the educational impact of programs that contribute to shaping individuals who are convinced that they are capable of dealing with the challenges that life brings. This is possible by building high self-esteem in people, including training in conscious living, individual responsibility, self-acceptance, assertiveness, and personal integrity. The higher our level of self-esteem, the better prepared we are to cope with our problems. The changes that have been made in educational programs are proven useful in developing desirable personality traits.

The basic goals of such education programs in security studies are:

- Acquisition of knowledge about security processes in various spheres of human activity and their theoretical interpretation

- Determining the relations between causes and effects in security studies and formulating homogenous knowledge (general security theory)

- Understanding the concepts, programs, and propositions for the complex security of people, nations, and states

- Choosing the appropriate criteria to evaluate national and global security. ${ }^{11}$

In human life, security is the fundamental and necessary condition of healthy and well-adjusted development, as well as self-realization in a social community. We assume that the state we define as "social security" is achieved when the following conditions are met:

- There is harmony between stability and instability in the important matters of life

- There is favorable ratio of predictable to unpredictable events

- There is no unfavorable change in the level of security that an individual has achieved, in terms of his career, vital factors, and short- and long-term plans

- There is no external control or interference in a person's individual values and private actions. ${ }^{12}$

\section{Personal Insecurity}

Insecurity is the most widely debated topic in the world today. Since the events of September 2001, when even the earth's best protected country was violated and its territory

11 Ibid.

12 Marek Rybakowski, "Kultura bezpieczeństwa na tle stanu bezpieczeństwa dzieci i młodzieży w ruchu drogowym," in Edukacyjne zagrożenia początku XXI wieku, ed. K. Pająk and A. Zduniak (Warsaw: Dom Wydawniczy Elipsa, 2003), p. 100. 
proved no longer immune from the social and human upheavals familiar to other lands, our collective feeling of insecurity has risen dramatically.

The way we experience insecurity depends on individual as well as general factors, both personal and cultural, subjective and objective. Still, one must admit that "insecurity" is a rather vague category, and that it could perhaps be more accurately analyzed and more precisely defined.

Naturally, there is no such thing as an absolute guarantee of security, either external or internal, and very often political battles are fought over the degree of security those in charge of the state are, or are not, able to offer. Moreover, even the most restrictive definition of security cannot be interpreted as the mere safeguard of the citizens' safety, but must instead also be understood as a system for the defense of their rights and duties - that is, as a global legal system. In this regard, it must be said that when we speak of confidence in the institutions of the state, of their credibility and efficiency, we are ultimately speaking of the quantum of actual security.

In a typical post-industrial society, economic growth rates are lower and more uncertain than they had previously been. Technological changes mean that stable employment in the manufacturing sector is no longer available on a mass scale, with implications for the job security of semi-skilled and unskilled workers and for class structure and the political interests associated with it. These changes create new social risks and new avenues for reform. The new social risks are the risks that people now face in the course of their lives as a result of the economic and social changes associated with the transition to a post-industrial society.

A paradox of a critical educational situation is the fact that independence, resulting from a strong emphasis on independence and personal responsibility, or, to a certain extent, an autonomous education, may also lead to isolation. In such cases, autonomy as a duty to the self to comply with general norms will disappear, resulting in abuse. The cases of such "independence" - an intense focus on the self-are observed when the process of education is dominated by the tendency to focus on the individual.

A substantial impact on the quality of the process of education in many social environments is exerted by the information technology revolution, which, on one hand, has brought so many valuable things into our lives, and, on the other, has resulted in a deep cultural crisis. It seems that a great myth of our era is the human right to the free expression of personality. This myth is often turned into the rule of: everyone can do anything, but not everyone and not anything.

A modern man, as Erich Fromm has put it, only seems to know what he wants; in fact, he wants what he is required to do. As a result of this process, he loses his identity, without which there is no real security for a free individual. Loss of one's identity intensifies the need to adapt to the obligatory models. ${ }^{13}$

One of the factors that dehumanize social life and threaten human existence are disturbances in the satisfaction of one's basic needs. These disturbances in terms of the need for security and stabilization, according to the experts in the field, lead to weaken-

13 Erich Fromm, Ucieczka od wolności (Warsaw: Czytelnik, 2000), 236-37. 
ing individuals' sense of purpose in life, which may result in obsessive-compulsive neurosis, reduction of the higher need to focus on issues associated with the sense of order, and a tendency to seek support in someone or something characterized by permanence.

In assessing situations we confront, fear plays a significant role, since it allows us to decide whether a given event will bring us benefits or only negative effects. However, the assessment is not always accurate. Individuals suffering from anxiety qualify various threats as being more menacing in comparison with persons with a stabilized level of fear. However, some threats are assessed as posing the same level of risk, regardless of any differences in the intensity of anxiety between individual persons. Drugs, terrorism, or a bomb attack usually result in strong fear reactions and are assessed as risky events, while recreational activities, such as skiing, swimming, or horseback riding are usually described as relatively safe and not posing a substantial risk. Assessment of a risky situation is influenced greatly by the degree of comfort in dealing with tasks that have not been encountered before. In such situations, no preventive measures are known that could allow us to avoid the negative effects of threats. Persons who fear failure upon the completion of a given task usually overestimate the associated risk.

It seems, nevertheless, that modern society, which is the source of the culture of individualism and relativism, only facilitates the emergence of narcissistic individuals. This term has not been used accidentally, because, as has been stated by Ch. Delsol, "a modern individual, even an adult, remains an unstable youth, characterized by incoherent desires, conflicting opinions, ... irresponsibility." 14

In a society of fluid modernity, individual achievements do not translate to permanent property, since assets turn into liabilities in the twinkling of an eye, and advantages turn out to be weaknesses. The circumstances of action and the subordinate strategies of action quickly become outdated. Taking advantage of experience as a source of knowledge and referring to strategies and tactics that had proven efficient in the past is thus unreasonable, as the challenges of the past did not take into account the sudden, usually unexpected changes in circumstances. Forecasting future tendencies on the basis of past events is even more risky, and is usually misleading. It is increasingly difficult to get reliable data, while infallible forecasts have become simply unimaginable. ${ }^{15}$

Passiveness is one of the most typical and yet pathological characteristics of men in modern society. A man wants to be fed, but fails to move, show initiative, even to digest the food that is provided to him. A man is not creative towards his heritage; he only gathers or consumes. Remaining passive, a man does not attempt to find his place in the world, and he is forced to give up his ideals and their attendant requirements. Therefore, he feels powerless, lonely, and full of anxiety. He finds it difficult to define himself, and his sense of integrity is low. Conformism, which seems to be the only way to avoid the unbearable fear, often turns out to be insufficient. ${ }^{16}$

14 Ibid., 91.

15 Zygmunt Bauman, Plynne życie (Kraków: Literackie, 2007), 6.

16 Erich Fromm, Rewolucja nadziei. Ku uczłowieczonej technologii (Poznań: Rebis, 2000), 64. 
Apart from passiveness, another factor that often influences individual security is obedience and submission. Today, obedience has become a somewhat forgotten virtue. Obedience is a questioned value, because the term is misunderstood, and it is often confused with submission. This confusion between obedience and submission is one of the most dangerous mistakes made in modern education. Submission means giving up freedom, or capitulation. Obedience, on the other hand, is disposal of the self in accordance with the established hierarchical order. Obedience is exercising one's freedom, but not against one's superiors; it is a choice of an attitude of cooperation with one's superior (educator). Teachers are the ones appointed to organize the lives of their pupils. Those who are responsible for discipline also need a positive reply to their actions from their subordinates - that is, they need obedience. Without obedience, there is no normal education. It is impossible to organize any kind of work, or a normally functioning community. Therefore, an upbringing in the spirit of an appropriate understanding of obedience is fundamental to building a free society.

In sociology, it is fashionable today to state that human problems can be analyzed without referring to the emotions associated with them. It is assumed that scientific objectivity requires the opinions and theories pertaining to men to be free from any emotional bonds. It should be emphasized that in Poland we are dealing with a cultural vacuum: on one side, there is a sense of freedom, while on the other we face the material degradation of many families. Moreover, in many Polish families we can observe the phenomenon of the so-called inheritance of poverty, and the intensification of pathological behaviors, such as suicide, addiction, aggression, and abuse. A modern family often experiences an increasing divorce rate, as well as relationships that have not been formally confirmed by the church or state. At the extreme, this flexibility that is brought to bear on open and temporary relationships can result in an acceptance of betrayal. This can lead to a commonly heard attitude, that "Everyone has the right to live the way they want to, so do what you want. You will have no obligations towards me, and I will have none towards you." This rule of education is encountered increasingly often in open and democratic societies.

The denial of any role for religion and the church is becoming more prevalent, and individuals' primary life orientations are becoming different. Religion and ethics increasingly seem to symbolize backwardness, and are seen as hindering progress. Modern society is "facing a specific crisis of humanity," which is marked by an increasing lack of confidence in our own human traits, in our very sense of existence. In many circles, we observe the disappearance of a "universal" - or universally educated - citizen.

The development of civilization (especially in the area of technology) complicates life in each of its aspects. It has positive as well as negative implications for human development; it broadens the range of threats. ${ }^{17}$ The border between the sphere of classical threats (that are historically continuous and traditional) and the sphere of freedom from

17 Such threats concern the fact of individual existence as well as health (physical or psychic) and social functions. Some new threats pose the risk of lowering the level of an individual's social condition. 
threat is gradually vanishing and being filled with new categories of threats, raising doubts about the difference between security and insecurity, health and disease, good and evil.

The globalization, informatization, and internationalization of socio-economic life are a plexus of dependencies that bring benefits and negative consequences. Especially turbulent are those that directly affect people and the basis of their existence, including dignified, secure, and healthy work conditions.

Modernity brings both progress and explicit threats. Let us analyze the impact of near-universal access to information. It seems as though we are becoming slaves of the technology that was supposed to free us. Although we have access to an unparalleled amount of information, we become more disoriented rather than well oriented. More elasticity denies us any elasticity at all, and more choices limit our freedom. ${ }^{18}$ What is worse, massive and unstoppable flows of information fill every blank space and distort the linear flow of time. Under continuous pressure - or, as Thomas Eriksen would say, the tyranny of the moment-we inhabit living spaces deprived of "before" and "after," "here" and "there." In reality, even the "here and now" is threatened, because the next moment arrives so soon that it becomes difficult to be in the moment that is now. We live staring a few seconds into the future. ${ }^{19}$

The pressure of time is not the only tension facing modern people. Their actions are not only the object of tyranny of the moment, but are also burdened with freedom of choice. As Anthony Giddens said, "life in a society of risk is life with [an] analytical attitude towards possible actions, positive and negative. ... Ahead of individuals and social groups in [a] post-traditional social world in every single moment there is an inexhaustible number of potential means of conduct (along with threats assigned to them)." ${ }^{20}$

An individual that wants to move forward with his career in a big company is hemmed in with uncertainty and anxiety. Every moment he can fail without achieving his goals, becoming a loser in the eyes of his family and friends. This anxiety increases his need for certainty. If he fails, despite the certainty that modern methods of decisionmaking gives, he doesn't have to blame himself, at least. One also needs certainty in the field of thoughts, feelings, and aesthetic impressions. Thanks to wide access to mass media and education, the individual quickly learns which thoughts are "good," which behaviors are proper, which feelings are normal, and which tastes are fashionable. If people stay sensitive to media signals, they can be sure to make no mistakes. Fashion newspapers tell us what style one should like, and book clubs let us know which books are worth reading. ${ }^{21}$

One of the most significant threats to personal and structural security is the dehumanization of education. The strong pressure to achieve success, along with the need to function under continuous rivalry and generational pressure leads (in extreme cases) to

18 Thomas Hylland Eriksen, Tyrania chwili. Szybko $i$ wolno plynacy czas $w$ erze informacji (Warsaw: PIW, 2003), 13-14.

19 Ibid., 11-12.

20 Anthony Giddens, Nowoczesność i tożsamość (Warsaw: PWN, 2001), 41.

21 Erich Fromm, Rewolucja nadziei (Poznań: Rebis, 2000), 78. 
the "machiavellization" of behavior. Pragmatism dominates over dialogue, discourse, and reflection. In the world of the new millennium we can notice dangerous tendencies in education to create an "information society" at the expense of an "education society." Attention is concentrated on creating cognitive abilities, and is oriented toward problems of modernity and the future at the expense of teaching values, which can result later in astonishing choices and decisions made by groups and individuals. ${ }^{22}$

\section{Education and Security}

In educational practice, more and more often we notice the need to construct the educational process in such way that gives prominent position to dialogue that is characterized by mutual understanding of the participants. ${ }^{23}$ The lack of dialogue, or discussion led in an atmosphere of mutual trust, can effectively weaken the effects of a range of educational actions of both teachers and parents.

In connection with modern threats, the role of school in this area is essential. That is where much of the content of "education for security" programs come from. This kind of education is one of the main parts of the didactic process, and represents one of a range of preventive actions that are centered on civil education, communication and health, and ecological education. Education for security is also one of the areas of preparation for work and life in the modern world.

Education for security consists of education in the following areas: civil society, economics, law, defense, social issues, and the environment. This is the system of education for responsibility for life and health, of both individuals and societies. Responsibility should be manifested in the ability to predict the outcome of actions undertaken; the ability to help victims of accidents and save lives; to intentionally follow the regulations and laws of the nation; to participate actively in efforts centered on maintaining the security of the local area, region, and country; in participation in relief efforts in response to natural disasters and man-made accidents. In consequence, a new formula for security education was adopted as mandatory in Poland's educational system. Specific contents of a program of education for security are realized in individual classes at different stages of education. Practice shows that the easiest method to prevent threats is a common and systematic approach to education.

22 There is an increasing sense among experts that there is a fundamental and urgent need of renewal of earlier modes of teacher education. It is necessary to equip teachers with a broad humanistic base - the knowledge of pedagogical, psychological, philosophical, and sociological thought - to thoroughly explore the world of values and their counters, threats and risk and educational ideals, to achieve the ability to discuss and finally to cooperate with young people. In the case of Poland, there is a clear asymmetry between expectations and educational needs and their realization (expenditures and desires to innovate). Education should ease the perception of reality as a set of values that are to be skillfully explored and internalized, so that they can be used to shape reality and themselves.

23

Tadeusz Siuda, ed., Ksztatcenie $i$ wychowanie młodzieży na rzecz bezpieczeństwa. Poradnik dla dyrektorów szkót i nauczycieli (Warsaw: ADAM, 2007), 27. 
This is why, on 21 October 2008, Poland's Ministry of Defense and Ministry of Education signed the agreement on cooperation. Considering the need to act together in realization of the program of education in traditional obligations and to cooperate in areas of civil, patriotic, and defense education of school youth, the Ministry of Education and Ministry of Defense agreed to cooperate in the following areas:

- Popularizing actions aiming to shape the historical, patriotic, and defense consciousness in the military and school environments

- Inspiring NGOs to undertake actions involved in the civil, patriotic, and defense education of students

- Supporting and promoting initiatives aiming to disseminate the tradition of Polish arms

- Providing organizational and material support to schools that bear the names of patrons that are related with the tradition of Polish arms and schools that realize the enlarged program of "Defense Education"

- Popularizing the idea of organizing trips to places that are part of Polish military history, and sport and defense camping trips

- Supporting the organization of "Open Barracks Days" and visiting tradition rooms, military museums, and national historic sites

- Using experiences of organizing patriotic events, school competitions, history contests centered around the history of Poland, as well as sports events and defense contests

- Inspiring school environments to participate in patriotic events organized annually.

In summary, security education is realized in Poland on three levels: school, institutional, and general. The objective that we seek to realize in high schools is an average of thirty hours of security education per year, with the number of hours rising each year within the school. This includes general education for security, along with education on the media, organization, and social associations, as well as on security bodies such as the police, fire service, and the army. Best practices in security education require us to teach safety and teach safely. 


\section{Bibliography}

Bauman, Zygmunt. Płynne życie. Kraków: Literackie, 2007.

Cieślarczyk, M.. "Społeczeństwa i społeczności na przełomie wieków - od bezpieczeństwa kultury do kultury bezpieczeństwa?" In Bezpieczeństwo w perspektywie socjologicznej, 31-32. Warsaw: WBBS, 2001.

Dryden, Gordon, and Jeannette Vos. Rewolucja w uczeniu. Poznań: Zyski i S-ka, 2003.

Dworecki, Stanislaw. "Zagrożenia bezpieczeństwa państwa." In Słownik terminów z zakresu bezpieczeństwa narodowego, 16. Warsaw: AON, 2002.

Eriksen, Thomas Hylland. Tyrania chwili. Szybko i wolno płynący czas w erze informacji. Warsaw: PIW, 2003.

Fromm, Erich. Rewolucja nadziei. Ku uczłowieczonej technologii. Poznań: Rebis, 2000.

Fromm, Erich. Ucieczka od wolności. Warsaw: Czytelnik, 2000.

Fukuyama, Francis. "Globalizacja bez końca." Gazeta Wyborcza 11 (2000): 23.

Giddens, Anthony. Nowoczesność i tożsamość. Warsaw: PWN, 2001.

Goźlińska, E., and F. Szlosek. Podręczny słownik nauczyciela kształcenia zawodowego. Radom: Institute for Technology of Operation, 1997.

Kunikowski, Jerzy. Przygotowanie obronne społeczeństwa. Warsaw: Bellona, 2001.

Naisbitt, John. Megatrends. Poznań: Zyski i S-ka, 1997.

Pielkowa, J. A.. "Pedagogika społeczna wobec zagrożeń współczesności." In Człowiek u progu trzeciego tysiąclecia. Zagrożenia i wyzwania, 61. Vol. I. Elbląg: Elbląska Uczelnia Humanistyczno-Ekonomiczna, 2005.

Rosa, Ryszard. Filozofia bezpieczeństwa. Warsaw: Bellona, 1995.

Rybakowski, Marek. "Kultura bezpieczeństwa na tle stanu bezpieczeństwa dzieci i młodzieży w ruchu drogowym." In Edukacyjne zagrożenia początku XXI wieku, 100. Warsaw: Dom Wydawniczy Elipsa, 2003.

Siuda, Tadeusz. Kształcenie i wychowanie młodzieży na rzecz bezpieczeństwa. Poradnik dla dyrektorów szkół i nauczycieli. Warsaw: ADAM, 2007.

Szymczak, M. Słownik języka polskiego. Vol. I. Warsaw: PWN, 1978.

winiarski, J. Ś. "Przywództwo jako osnowa edukacji dla bezpieczeństwa." Zeszyty Naukowe AON 1 (2001): 134. 